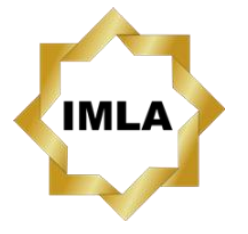

Available online:

http://journal.imla.or.id/index.php/arabi

Arabi : Journal of Arabic Studies, 5 (1), 2020, 43-50

DOI: http://dx.doi.org/10.24865/ajas.v5i1.149

\title{
SUNDANESE PHONOLOGICAL INTERFERENCE INTO ARABIC LANGUAGE IN KETAPANG SOCIETY
}

\author{
Dwi Noviatul Zahra', Muhammad Afif Amrulloh², Leviana², \\ Suci Ramadhanti Febriani ${ }^{3}$ \\ 1 Universitas Islam Negeri Sunan Kalijaga Yogyakarta, Indonesia \\ ${ }^{2}$ Universitas Islam Negeri Raden Intan Lampung, Indonesia \\ ${ }^{3}$ Universitas Islam Negeri Maulana Malik Ibrahim Malang, Indonesia \\ E-mail : dwinoviatulzahra11@gmail.com
}

\begin{abstract}
Ketapang is a village in Limau sub-district, Tanggamus district, Lampung province, Indonesia, inhabited by Sundanese speakers. This condition contributes to the variation of Arabic pronunciation, causing irregularities or difficulties known as disturbances. Linguistic phenomenon as a form of language development, something important happens in Arabic. This research was to study phonological interference forms in Sundanese. This research used a qualitative descriptive method with data collection methods through interviews, observations and hearing that comes to the speech of the Ketapang community. The results showed several changes in the phonological change phenomenon, namely phoneme changes and word changes. This study contributes to the knowledge of language development that occurs from phonological disorders in Sundanese to Arabic, thus providing a great deal of knowledge about Arabic linguistic studies.
\end{abstract}

Keywords: phoneme, phonology, interference, Arabic language

\begin{abstract}
Abstrak
Desa Ketapang adalah desa yang mayoritas penuturnya adalah orang Sunda yang berdomisili di kecamatan Limau, kabupaten Tanggamus, provinsi Lampung. Kondisi ini berkontribusi pada keragaman pengucapan bunyi bahasa Arab, sehingga ada penyimpangan atau kebingungan yang sering terjadi atau dikenal sebagai gangguan. Fenomena linguistik ini sebagai bentuk perkembangan bahasa, terutama sesuatu yang terjadi dalam bahasa Arab. Penelitian ini bertujuan untuk mengetahui bentuk-bentuk interferensi fonologis dalam bahasa Sunda. Metode penelitian ini menggunakan pendekatan deskriptif kualitatif dengan metode pengumpulan data melalui wawancara, observasi dan dokumentasi yang berasal dari pidato komunitas Ketapang dan sumber data didapat dari komunitas Ketapang. Hasil penelitian menunjukkan bahwa ada beberapa jenis perubahan suara dalam fenomena gangguan fonologis, yaitu pengurangan fonem dan perubahan huruf. Studi ini berkontribusi pada pengetahuan tentang perkembangan bahasa yang terjadi dari gangguan fonologis dalam bahasa Sunda ke bahasa Arab, sehingga memberikan banyak pengetahuan tentang studi linguistik Arab.
\end{abstract}

Kata Kunci: fonem, fonologi, interferensi, bahasa Arab 


\section{Arabi : Journal of Arabic Studies}

\section{Introduction}

Ketapang is one of the villages in Limau sub-district, Tanggamus district, Lampung province. The majority of the people in the Ketapang village are Sundanese so that the language of communication is used as an expression of interaction between people is Sundanese. This condition certainly has an effect on the speech patterns uttered by the people of Ketapang village, especially on the religious aspects. The societies are Moslem and they live their life in Islamic ways which originates in Arabic, producing the various Arabic linguistic phenomena spoken by the people of Ketapang village.

According to Stephen, language is usually studied in relation to assemblages of words and rules or languages and, in many views, these are ascribed to the 'workings' of a person or mind/brain (Issue, 2019). The study of language also should be distiguished from oral or written pattern in order to minimize the confusion in acquiring and understanding the information. Victor assums that the development of oral language presents several milestones where emerging behaviors clearly intertwine with maturational changes in production processes (Boucher \& Lalonde, 2015).

Language in particular is a clear means of communication and a medium that connects interaction among individuals (Aseeyah Kuwing, 2017). By having good interaction, each of individual can communicate well, build good comunication, and share information. Without language we cannot communicate each other, meaning that language takes an important part in communication.

Foreign languages are one of communication tools and non-native languages in a country. Foreign languages are usually well studied for communication or religious languages. In fact, nowadays the society also accept mother tongue in several languages (phonological, syntactic, semantic and textual) (Azechi, 2016). Martin also revealed that culture and language cannot be separated from social interaction (Martin et al., 2019). As revealed by Banban, all ethnic groups have multiple identities and mechanisms in language (Banban, 2018).

Every individual must have their own mother tongue. According to (Bialystok, 2017; Grosjean, 2010) as cited in Leeuw \& Celata, generally it is assumed that most people in the world speak more than one language (Leeuw \& Celata, 2019). The phenomenon of contact between two languages or more will lead to conditions of mutual influence on the application of first language or mother tongue rules in the use of a second language or vice versa. Charles stated that a fundamental goal of linguistic inquiry has been to characterize the complex and largely unconscious knowledge that permits human beings to speak their first language like a native speaker, with little apparent effort (Chang, 2019). The use of language alternately can cause confusion in language usage, known as interference (Lubis, n.d.).

Christopher states that in their second language (L2), many speakers have an accent that is shaped by their first language (L1) and is therefore perceived as non-native-like. Sometime this phenomenon will significantly affect the process of acquiring languange and making confusion.

Interference is the biggest, most crucial, and most dominant deviation phenomenon in language development. It also occurs on Arabic which cannot be separated from interference, especially in vocabulary related to the culture and nature of the local environment. According to Flege's Speech Learning Model, the speech sounds of a bilingual languages contain dinone common phonological space. It means that it will influence the articulation of speech sound. While, Fabian assumes that response measures in linguistics and phonetics are often a function not of a single predictor but of many predictors jointly, reflecting a move away from mono-causal to multifactorial explanations (Bergmann et al., 2016).

Phonology is one of the branches in linguistics that talks about the sound, whether its aspects or how it generates or the language sounds are transmitted from the aspect of the function (Amrulloh, 2017). Interference phenomena that occur in a language to another are difficult to avoid. One of the interference phenomena is the phonological aspects. Phonology is the outcome 
of practical processes: a child learning to comprehend and pronounce a particular language. One of the examples of phonological interference in the Sundanese language of Ketapang people into Arabic is "apdhal" and "paedah" words. The word "apdhal" and "paedah" is the influence of the existence of a mother tongue or Sundanese language that influence the utterances of Arabic words (Messum \& Howard, 2015).

Monna argued that individual non-native phones may be assimilated to the L1 phonological sys-tem in one of three ways: (a) categorised: a non-native phone may be assimilated to an L1 phoneme and be perceived as anexcellent, moderate, or poor exemplar of that category, (b)uncategorised: a non-native phone may not be perceived assimilar to any one particular L1 phonological category, andso falls in an untuned region in between categories, or (c) nonassimilable: a non-native phone is not perceived asspeech and so falls outside the listener's L1 phonologicalspace (Faris et al., 2018). Then, it causes discrimination predictions based on the various ways pairs of contrasting phones are assimilated. Accordingly, the two contrasting phones are categorised as different L1 pho-nemes (aTwo-Category assimilation, TC), discrimination accuracy should be excellent because the non-native contrast happens to correspond to an L1 phonological contrast.

Taehong states that in accounting for phonological versus phonetic aspects of the voicing contrast, Keating $(1984,1990$ a) suggested that while the phonological feature (such as $[ \pm$ voice]) may be required to explain the phonological contrast between voiced and voiceless stops within each language (see also Kingston \& Diehl, 1994), the phonetic features such as voiced, vl. unasp:, vl. asp: are required to explain how stops are phonetically implemented between languages. It means that the distinction is needed in order to make them easy to understand. But the thing that should be noted is that the variation in language is highly varied. Thus, deeper research on is needed.

As a research conducted by Udin Suryansyah examined the form of phonological and grammatical interference in the Bima language into Indonesian which was spoken by BimaDompu students who were in the Mataram University campus environment. The results of his research show that the form of interference that occurs is vocalist interversion of consonant phonemes, vocal phoneme interference, interference of vowel phoneme changes, interference of vowel phoneme changes, vocal phoneme interference, grammatical aspects of morphology and syntax (Udin Suryansyah, 2017). While, this research discussed about the various forms of interference with phonological aspects of the Sundanese language used in Ketapang community.

The article written by Eko Widianto discussed the sociolinguistic phenomena that occured in the community of Islamic boarding schools. Habits that often occur in the Islamic boarding school (pesantren) community are language interference that has been equally understood by the speakers. This raises two possibilities, namely language integration or a shift in a language system (Eko Widianto, 2015).

Furthermore, the research by Bukhari Muslim and Syukrina Rahmawati discussed the form of phonological interference and the lexicon of the Malay language in Indonesian which was spoken by former Indonesian Workers (TKI) in East Lombok district. The results of the study show that there is interference of vowel phoneme changes /a / to / e /. Then the vocal phonemation, change, dissolution of the consonant phoneme, consonant removal / $\mathrm{r} /$. Phonological interference in the form of lexicons such as the mention of [motor] in Indonesian has become [gusting] in Malay, [belok] in Indonesian has become [pusing] in Malay (Muslim, 2018).

The other study by Thoyib I.M and Hasanatul Hamidah focused on phonological interference of non-Arabic students at Al-Azhar University in Indonesia. This interference occurs because of the difficulty of pronouncing phonemes that do not exist in Indonesian. This phonological interference disorder is influenced by two things, the duration of learning and the frequency of speaking of language in everyday life (Arabic, Thoyib, \& Hamidah, 2017). 


\section{Arabi : Journal of Arabic Studies}

Martina Kihi-kihi's study discussed phonological interference in the Tobelo community found that the form of phonological interference in the form of phoneme addition and phonological interference in phoneme reduction. While the factors causing Galela language interference in Tobelo language are bilingualism, mother tongue, geographical location, and mixed marriages (Martina, 2015).

Last but not least, David Samuel Latupeirissa found that Kupang Malay language interference with Indonesian phonologically has five types of phonemeal interference at the beginning of the word, phonemeal interference in the middle of words, interference with phoneme changes, and interference with phoneme changes. Some words that appear after the occurrence of phonological interference including Kupang Malay language loanwords are found in the Kupang Language Dictionary (Latupeirissa, n.d.)

Thus, this study was conducted to find out the forms of phonological interference that occurred in the Sundanese speakers of the Ketapang community into Arabic. Arabic is as an Islamic language in reading the verses of the Koran, prayers, and so on. Speakers of the Sundanese in Ketapang community speak Arabic with inseparable influence or linguistic interference in the form of interference, namely specific phonological interference or sound.

\section{Method}

This type of research is qualitative research. Seen from its nature, this research included descriptive approach that only describes and explains the phonological interference of Arabic language in the Ketapang community (Hamzah, 2015). The stages of this research were the provision of data, data analysis and presentation of the results of the analysis. Data was obtained from the speakers of the Ketapang village community as Sundanese speakers.

Data collection techniques used by the researcher was interview carried out to obtain data or information as much as possible and as clear as possible to the subject of research. The type of interview was unstructured interviews. This interview was to obtain data about phonological interference that occurred in the Ketapang village society. The questions were open-ended questioned and the flow of conversation could be predicted and flexible but controlled.

Then, observations are used as data collection related to the environment of the community. In this study, the researcher did non-participant observation by only observing data sources in the daily activities of the Ketapang village society in Tanggamus District regarding the existence of phonological interference.

Documentation was conducted on important and useful things for research, such as notes on interview results, general descriptions covering geographical location, list of names of educators, research photo, and others. While the data analysis used the distributioinal method, namely the method by which the determinant is the language itself which is part of the language studied.

\section{Result and Discussion}

Discussing the phonological interference of the Sundanese language of the Ketapang community into Arabic, the researcher classified the distribution of sounds that experienced phoneme reduction and the change of letters as follows:

\section{Phoneme Reduction}

\section{أذان Adzan - Adan}

The Ketapang society said the adzan word changed to adan, resulting in a reduction in phonemes which caused phonological interference. Phoneme reduction in pronouncing the word $/ \mathrm{dz} /$ changes into $/ \mathrm{d} /$. Arabic phoneme $/ \mathrm{dz} /$ produced with the tip of the tongue that touches or approaches the top of the tooth, or undergoes a process of apiko dental sliding sound. Phoneme /d/ is a characteristic feature of the regular friction of the two vocal cords. 


\section{Tsalju - Salju ثلج}

Phoneme /ts/ process of sound relaxation with phonetic characteristics that change to $/ \mathrm{s} /$. The Arabic phoneme /ts/ is produced with the tip of the upper tongue approaching the upper teeth, or undergoing a process of apiko-dental sliding sound while phoneme $/ \mathrm{s} /$ is a feat ure of voiced shear phonemes belonging to the Sundanese language.

\section{Kursiyy - Korsi كرسيّ}

Elimination or omitting one or more phonemes in the word kursiy which turns into corrections resulting in reduced phonemes. At the end of the word which is phoneme $/ \mathrm{y} / \mathrm{changes}$ into /i/ or in other words the addition of yā an-nisbah makes an ism which previously has the tribute of the tanwin to change its pronunciation to [i] without double yā or syaddah. This habit of pronunciation in Arabic was carried away after the words changed into Sundanese.

\section{Substitution (Transliteration)}

The researcher found a word that experienced a letter change that was done by a Sundanese speaker, namely:

\section{Rahim - rahim الرحيم}

Substitution of letters (transliteration) The letter/ح/ (h) becomes /o/ (h) in the Ketapang community ie the example in the word الرحيم (ar-rahim) changes to الريم (ar-rahim). Changes in letter sound $/ \tau /$ (h) to (h) phonological interference data cards number 01 who was Rohani, occured when she lead them reciting بسم الله الرحمن الرهيم (bismillahir rahmānir rahīm). They recited

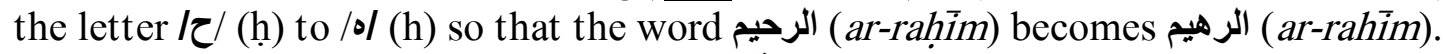

The letter/ح/(h) is a pharynk letter (حلقية) while/o/ (h) is the larynk / glottal letter (حنجرة). The two letters have the same properties, namely hams (vague), rakhāwah (weak), istifäl (down) and infitāh (open). Sundanese speaker do not recognize the letter $/ \tau /($ h) so it changes the sound of the letter/ / / (h) to / $/(\mathrm{s})$ due to the similarity in the nature, influence of the mother tongue and the very close articulation place.

\section{Shirätha - sirāthabالصراط}

The researcher found the word that experienced the change in letter/ص/(sh) to / / (s) in phonological interference data card number 03, who was Rukmini, in the afternoon when the routine tahlil recitation of women's group began. When reciting al-Fätihah verse 6: الصراط المستقيم (shiräthal mustaqīm), so the word صراط (siräthal) which results in phonological interference or sound change.

The letter/ص/(مفخم) while (sh) is a velarized letter (s) is also an alveolar letter (لثوية) the two letters have the same character, namely rakhāwah (weak), must be (vague). while the difference in nature is /w/ (s) has the istifäl (down) and infitäh (open) while /ص/ (sh) has the properties of Istila (raised) and ithbāq (closed). In Sundanese do not recognize the letter/ص/(sh) so that it changes the sound of the letter/ص/(sh) to $/ \mathrm{m} /$ (s) due to the similarity in the nature and influence of the alphabet of the mother tongue.

\section{Mustaqîm - mustakîm المستقيم}

Ketapang society did not use phonological interference in the letter substitution / (q) to /S/ (k) on the phonological interference data card number 03 with the speaker, Rukmini, and it occured during afternoon when the routine tahlil recitation of women's group began. When

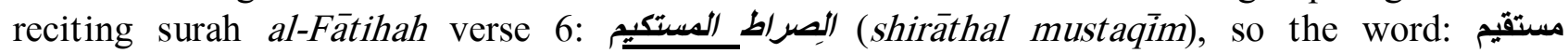
(mustaqim) becomes مستكيم (mustakim) so that it causes a sound change.

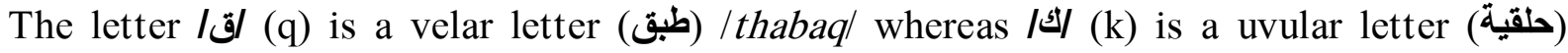
/halqiyah/ the two letters have the same properties, namely the letter /5/ (k) has hams (vague), while the letter قاقl (q) has istifâl (down) and qalqalah (reflection) properties. In Sundanese, the 


\section{Arabi : Journal of Arabic Studies}

qalqalah (reflection) like tahe letter اقG (q) so that there is a change to the sound / $/$ (k) due to the similarity of the character and influence of the alphabet of the mother tongue.

\section{الذين Al-ladzina - al-ladina}

Phonological interference occurred in Ketapang society conducted by speaker Rukmini with the number 04 interference data card number and the utterance occurred during routine tahlil recitation every Friday, when reciting the surah al-Fätihah namely: صراط الادين (shiräthal ladina). Rukmini recited letters /ذ/ (dz) to /د/ (d) so it changes the word صراط الأنين (shirathal ladzina) becomes صراط الدين (shiräthal ladina) which results in phonological interference.

The letter / ذ/ين أسناني (dz) is an interdental letter while the letter/د/ (d) is an alvodental letter (أسنا نية لثوية). Both letters are istifal (down), infitah (open). There is a difference, in the character letter /د/ (d) is syaddah (strong) while /ذ/ (dz) is rakhāwah (weak). In Sundanese, interdental consonants (vibrations), which include the letters $/ \mathbf{j} /$ (dz) do not exist. So, they experience a change or deviation of sound / $/ /(\mathrm{dz})$ to $/ \mathrm{s} /(\mathrm{d})$ due to the similarity of the characters, the alphabetical influence of the mother tongue, and adjacent articulation place. Interdental sounds د، ص، ر، ض a. occur due to interrelated articulation processes between the letters $ر$ ر

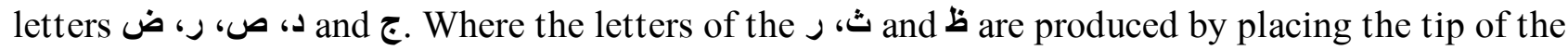
tongue between the upper and lower teeth without closing the airflow perfectly (Amrulloh, 2019).

\section{Naffătsāti - naffāsāti النقتث}

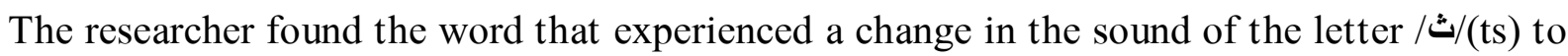
(naffääti). Here is an example of changing the letter / النفست (s) that (ts) to (s) in Ketapang society. Phonological interference data card number 08, who was Junairah, and utterances occured during afternoon when the routine tahlil recitation of women's group began.

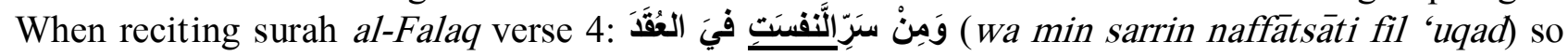

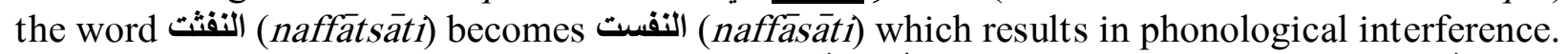

The letter /ث/ (ts) is an interdental letter (بين الأسنانية) while the alveolar letter (لثوية) both letters have the same characteristics, there are rakhäwah (weak), istifăl(down), infitäh (open) and hams (vague). Whereas the difference between the two is letters /w/ (s) having the character of shafir (seruit) while the letters / $/ /$ (ts) in Sundanese do not exist such as interdental consonants including letters / $/$ (ts) so that it changes the / $/$ (ts) to $/ \omega /(\mathrm{s})$, due to the similarity in character, adjacent articulation place and alphabetical influence of mother tongue.

Language gives the opportunity for speakers to understand the relationship between language and other cultural phenomena (Van Zyl \& Meiselman, 2016). Culture can affect language in the community (Henne-Ochoa, 2018). Some of the causes of errors in speaking Arabic in the ketapang community that become the main factor are the wrong habituation when adding or subtracting phoneme pronunciation, so that it becomes a habituation in society and is considered a truth. This habit is shown when tahlil events are held routinely and the acquisition of language obtained is also limited to the native speaker community, so the mother tongue is very influential and dominant in the pronunciation of an Arabic word. This is confirmed by Abid that distinguishes mother tongue and Arabic as well as being one of the causes of changes in pronunciation that are done unconsciously (Abid Thyab, 2016).

Senowarsito argues one of phonological errors is caused by the disruption of their mother tongue's phonological and orthographic systems (Senowarsito, 2019). Mother tongue communication issues the smoothness of the community in reciting alphabet, words and even intonation in using Arabic language. The quality of this pronunciation needs best practice to reduce errors in pronunciation (Azechi, 2016) or pronunciation changes by the Ketapang society. The phonological issue needs to be seriously considered because it seems to still occur clearly even 
in the Ketapang community, the current language that influences their fluency in Arabic, especially in the recitation of $\bar{a} \bar{a} \bar{t}$ that aim to worship.

It is hoped that the findings of this study can be a reference in making excellent learning materials with the consideration of making the Ketapang community have better pronunciation. The concept of agreement is accepted for language acquisition, while the term learning is often used for the same thought. Raheem said the terms of the terms were more academic and the terms of learning were appropriate. This term is mostly used for the first language which means it is different from learning if we consider it in the first language compared to the second language (Raheem, 2019). On the basis of improvements in language learning, this can minimize the mistakes of phonemes uttered by a person to the order of the community.

\section{Conclusion}

The linguistic phenomenon of phonological interference can occurs to the all language systems. Inter-language interactions conducted by speakers with their bilingualism contribute greatly to the development of a language. Many languages experience phonological interference from a system of other languages. Mother tongue as the initial language of the speaker also influences the second language phonological interference. Of course this condition is a challenge for every language speaker in the context of the existence of a language in the realm of interaction between language systems. The positions of makhraj, the different alphabets and similarity in the character of the letters are also able to support the occurrence of language phonological interference. The researcher hopes for the further research on phonological interference to obtain the results of studies that are more specific and profound.[]

\section{References}

Abid Thyab, R. 2016. "Mother-Tongue Interference in the Acquisition of English Articles by L1 Arabic Students", Journal of Education and Practice, Vol. 7, No. 3.

Amrulloh, Muhammad Afif., \& H. Hasanah. 2019. “Analisis Kesalahan Fonologis Membaca Teks Bahasa Arab Siswa Madrasah Tsanawiyah Lampung Selatan”, Arabiyatuna: Jurnal Bahasa Arab, Vol. 3, No. 2.

Amrulloh, Muhammad Afif. 2017. “Analisis Perubahan Fonologis Dalam Pembentukan Kalimah Mu'arrabah", Arabiyat: Jurnal Pendidikan Bahasa Arab dan Kebahasaaraban, Vol. 4, No. 2.

Amrulloh, Muhammad Afif. 2017. 'Kesamaan Bunyi pada Sajak (Kajian Fonologi al-Qur' an dalam Surat al 'Asar)", Jurnal Al Bayan: Jurnal Jurusan Pendidikan Bahasa Arab, Vol. 9, No. 1.

Azechi, N. 2016. “The Influence of Mother Tongue on Young Children's Rhythmic Behaviour in Singing”, European Journal of English Language, Linguistics and Literature, Vol. 3, No. 2.

Banban, D. 2018. "Harmony in diversity: an empirical study of harmonious co-existence in the multi-ethnic culture of Qinghai", International Journal of Anthropology and Ethnology, Vol. 2, No. 1.

Bergmann, C., A. Nota, S.A. Sprenger, \& M.S. Schmid. 2016. "L2 immersion causes non-nativelike L1 pronunciation in German attriters", Journal of Phonetics, Vol. 58.

Boucher, V. J., \& B. Lalonde. 2015. "Effects of the growth of breath capacities on mean length of utterances: How maturing production processes influence indices of language development", Journal of Phonetics, Vol. 52.

Chang, C. B. 2019. "Language change and linguistic inquiry in a world of multicompetence: Sustained phonetic drift and its implications for behavioral linguistic research", Journal of Phonetics, Vol. 74. 


\section{Arabi : Journal of Arabic Studies}

Faris, M. M., C.T. Best, \& M.D. Tyler. 2018. "Discrimination of uncategorised non-native vowel contrasts is modulated by perceived overlap with native phonological categories", Journal of Phonetics, Vol. 70.

Hamzah, K. 2015. "Interferensi Fonologis Jawa-Sunda Masyarakat Kedungreja Cilacap Pada Penuturan Bahasa Arab", Journal of Arabic Learning and Teaching, Vol. 4, No. 1.

Henne-Ochoa, R. 2018. "Sustaining and revitalizing traditional Indigenous ways of speaking: An ethnography-of-speaking approach", Language and Communication, Vol. 62.

Issue, S., A. Berthoz, \& N. Love. 2019. "Simplexity", languages and human languaging, Vol. 71.

Kuwing, A. 2017. "Interferensi Fonologis Bahasa Melayu Pattani Dalam Berbahasa Indonesia Mahasiswa Thailand Di Universitas Muhammadiyah Surakarta”, Mabasan, Vol. 11, No. 1.

Latupeirissa, D. S. n.d. "Interferensi Fonologis Bahasa Melayu Kupang Terhadap Bahasa Indonesia Dalam Peristiwa Tutur Masyarakat Melayu Kupang: Sebuah Kajian Deskriptif", unpublished article.

Leeuw, E. De., \& C. Celata. 2019. "Plasticity of native phonetic and phonological domains in the context of bilingualism", Journal of Phonetics, Vol. 75.

Lubis, M.I.S. n.d. Interferensi Fonologi Bahasa Indonesia Ke Dalam Bahasa Arab. Medan: Universitas Sumatera Utara.

Martin, C., B. Woods, \& S. Williams. 2019. "Language and Culture in the Caregiving of People with Dementia in Care Homes - What Are the Implications for Well-Being? A Scoping Review with a Welsh Perspective", Journal of Cross-Cultural Gerontology, Vol. 34, No. 1.

Martina, K.K. 2015. Interferensi Fonologis Bahasa Galela Ke Dalam Bahasa Tobelo. Manado: Universitas Sam Ratulangi.

Messum, P., \& I.S. Howard. 2015. "Creating the Cognitive form of Phonological Units: The Speech Sound Correspondence Problem in Infancy Could be Solved by Mirrored Vocal Interactions Rather than by Imitation", Journal of Phonetics, Vol. 53.

Muslim, B. 2018. "Kata Kunci”, Jurnalistrendi, Vol. 5, No. 2.

Raheem, K. J. 2018. "The Role of First Language on The Second Language Acquisition", International Journal of Kurdish Studies, Vol. 4.

Senowarsito., \& S. N. Ardini. 2019. "Phonological fossilisation of EFL learners: The interference of phonological and orthographic system of L1 Javanese", 3L: Language, Linguistics, Literature, Vol. 25, No. 2.

Suryansyah, Udin. 2017. Interferensi Fonologi Dan Gramatikal Bahasa Bima ke Dalam Bahasa Indonesia pada Komunitas Mahasiswa Bima-Dompu di Lingkungan Universitas Mataram. Mataram: Universitas Mataram.

Van Zyl, H., \& H.L. Meiselman. 2016. "An update on the roles of culture and language in designing emotion lists: English, Spanish and Portuguese", Food Quality and Preference, Vol. 51. 